\title{
OSMOTIC PRESSURE MEASUREMENTS OF SERUM AND ASCITIC FLUID IN PATIENTS WITH CIRRHOSIS OF THE LIVER
}

\author{
BURTON GIGES AND HENRY G. KUNKEL \\ (From the Hospital of The Rockefeller Institute for Medical Research, New York, N. Y.)
}

(Submitted for publication July 17, 1953; accepted October 7, 1953)

Numerous contributions regarding the pathogenesis of ascites and edema have been made since Starling's first description of the balance between serum and tissue hydrostatic and osmotic forces. The original concept (1) proposed that, at equilibrium, serum protein osmotic pressure minus tissue fluid osmotic pressure equals capillary hydrostatic pressure minus tissue hydrostatic pressure. Direct application of this relationship to the problem of ascites received relatively little attention until recently when Mankin and Lowell (2) and James (3) employed this approach for the approximation of the degree of elevation of portal pressure. Further clarification of the applications and limitations of this principle to the pressure relationships in the formation of ascites represented the primary purpose of the present study.

The importance of the serum protein osmotic pressure was emphasized in early studies suggesting that a critical level existed, approximately 240 to $270 \mathrm{~mm} . \mathrm{H}_{2} \mathrm{O}$, below which edema would occur (4-8) This view was questioned by Kylin, however, who performed plasmapheresis experiments in rabbits and was able to obtain very low serum osmotic pressure values without edema (9). However, when he added salt to the diet, the animals became edematous even at serum osmotic pressure levels near normal. The clinical counterpart of these experiments appears in the cases described in the literature (10) in which edema was absent at serum osmotic pressures below $200 \mathrm{~mm}$.

A similar concept has developed concerning the relationship of the serum osmotic pressure to the formation of ascites. Butt, Snell, and Keys (11) found that ascites occurred most frequently when the serum osmotic pressure was below $240 \mathrm{~mm}$. Bjørneboe, Brun, and Raaschou (12) emphasized this critical level and concluded that a reduced serum osmotic pressure was the principal factor in the pathogenesis of ascites and that portal hypertension played a subordinate role. As they pointed out, the data were obtained from patients with cirrhosis following hepatitis. Other investigators (13) reached similar conclusions stating that ascites was probably not due to liver disease when the serum osmotic pressure was greater than $300 \mathrm{~mm} . \mathrm{H}_{2} \mathrm{O}$. Armstrong (14) suggested a critical level for the "effective" osmotic pressure (serum osmotic pressure minus ascitic osmotic pressure) below which ascites occurs.

Indirect evidence against the concept of a strict relationship between serum osmotic pressure and ascites formation has been brought forth by several investigators $(15,16)$. Evidence was obtained in the present study indicating that the type of cirrhosis is an important factor to be considered in evaluating the relationship between ascites and serum osmotic pressure levels.

\section{METHODS}

Osmotic pressure measurements were made on serum and ascitic fluid from 46 patients with various types of cirrhosis of the liver, and from a few patients with Chiari's syndrome, idiopathic hypoproteinemia, nephrotic syndrome, and carcinoma of the ovary. The patients were maintained in a state of equilibrium by a controlled low sodium diet, and were neither increasing nor decreasing the amount of ascites. None had sufficient fluid to produce a tightly distended abdomen. Comparisons between serum and ascitic fluid were made in 20 patients on samples obtained simultaneously.

The apparatus ${ }^{1}$ used for the measurement of osmotic pressure was patterned after the Hepp osmometer (17), and consisted of an osmotic cell, horizontal capillary, and water manometer. The osmotic cell was made of two lucite plates ( 87 by 87 by $19 \mathrm{~mm}$.) held together with perforating screws. The upper plate had a circular hole $50 \mathrm{~mm}$. in diameter, and the lower plate had a hole just large enough to admit the tip of the capillary. Between the plates were a rubber gasket, membrane, and disc of filter paper moistened with the solution described below. The purpose of the filter paper (Schleicher and Schuell number $604,50 \mathrm{~mm}$. diameter) was to prevent drying of the membrane, obliterate dead space, and allow rapid transfer of fluid across the membrane. Its use

1 Constructed by Mr. C. Galati (4). 
has been recommended by numerous investigators $(2,18-$ 21). The horizontal capillary was a $1 \mathrm{ml}$. pipette bent to an L-shape. The tip of the short limb was ground down to fit tightly into the hole in the lower plate. The other end was connected to the manometer. The manometer consisted of two long glass tubes filled with water and mounted vertically on a wooden frame. The tubes were connected to each other, to the horizontal capillary, and to a levelling bulb which rested on a balancing chain. The levels of the menisci were read on a millimeter scale placed behind them, and the difference between them represented the hydrustatic pressure exerted on the solution in the horizontal capillary. The meniscus of this latter solution was observed in a horizontal cathetometer.

When the ionic strength of the solution outside the membrane exceeds 0.1 Molar concentration, the osmotic pressure is not affected by small changes in $\mathrm{pH}$, carbon dioxide tension, or salt concentration $(19,22,23)$. In the present experiments, $0.145 . \mathrm{M}$ sodium chloride was used as the outer solution in the filter paper and horizontal capillary. Saline has been shown to be as effective as an ultrafiltrate of serum, although equilibrium may take somewhat longer (24). In the early determinations, $0.15 \mathrm{M}$ phosphate buffer was used, but no differences were encountered. The membranes employed in this study were mostly the superdense ultrafine filters of Schleicher and Schuell. The diameter was $75 \mathrm{~mm}$., the average pore size less than $5 \mathrm{mu}$, and the " $\mathrm{T}$ " values ${ }^{2}$ exceeded 500 minutes. Although these membranes were much slower than the more permeable "very dense" membranes, many of the latter were found to allow passage of serum proteins and were therefore unsatisfactory. The membranes were stored in 1 per cent $\mathrm{HCl}$ at $4^{\circ} \mathrm{C}$. to prevent bacterial contamination. They were washed in saline solution for several days before being used $(25,26)$. Membranes handled in this fashion were suitable for six to eight weeks. In earlier determinations, membranes were prepared in the laboratory according to the technique of Pierce (27), as modified by Mankin and Lowell (2). It was subsequently decided to use the membranes prepared commercially, however, since special apparatus for the rigid control of humidity and temperature is usually required to obtain reproducible pore size, thickness, and permeability.

For the actual measurement, $2.0 \mathrm{ml}$. of the sample were delivered onto the membrane, and the cell was covered. The manometer was then readjusted frequently until the meniscus in the horizontal capillary remained stationary for a minimum of thirty minutes. The usual length of time required to attain equilibrium was two to six hours. Leakage of protein through the membrane was suspected if the pressure was not sustained for the required time; it was proven by detecting faint traces of protein in the solution in the horizontal capillary. Correction factors for the capillarity of the horizontal capil-

2 "T" value is the time required for $100 \mathrm{ml}$. of distilled water to flow through $100 \mathrm{sq}$. cm. of membrane area, at room temperature, under a pressure of $760 \mathrm{~mm}$. $\mathrm{Hg}$ (Schleicher and Schuell).

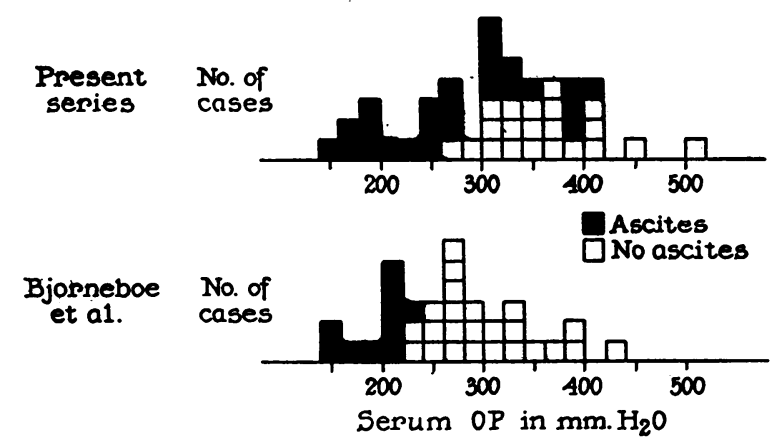

Fig. 1. Serum Osmotic Pressure Levels in 46 Patients With Cirrhosis With and Without Ascites Illustrated Graphically and Compared with Levels Found in a Special. Series Reported from Denmark (12)

lary and the hydrostatic difference between the sample and the outer solution level were determined by the net hydrostatic pressure required to prevent the movement of the meniscus with saline on both sides of the membranes. When the membrane is in place, the same side must face upward each time $(24,26)$. The determinations were made at room temperature since, in this type of osmometer, the osmotic pressure is not altered by minor changes in temperature (17). The error of the method ( 2 to 6 per cent) corresponds to that obtained by previous investigators whether or not temperature control was employed $(2,12,19-22)$. This error was obtained by measuring samples of a standard 6 per cent albumin solution ten times. The range of results was $330 \pm 7 \mathrm{~mm}$. $\mathrm{H}_{2} \mathrm{O}$ (2 per cent error).

\section{RESULTS}

Serum osmotic pressure determinations in various types of cirrhosis are plotted in Figure 1. Values below 260 millimeters of water are uniformly associated with ascites. In contrast to Bjфrneboe's series, however, ascites also occurred despite serum osmotic pressure levels up to 420 $\mathrm{mm}$. of water. In an attempt to explain this apparent discrepancy, the cases were divided into three etiologic groups (Figure 2). In five cases of biliary cirrhosis (four primary and one secondary), the serum osmotic pressure exceeded 340 $\mathrm{mm}$. of water. None of these patients had ascites, although portal hypertension was suggested in three by the presence of esophageal varices. Included in the classification "cirrhosis of unknown etiology" are patients in whom no history of alcoholism or nutritional deficiencies was obtained. This group consists mostly of young adult females who have been described elsewhere (28). Some 


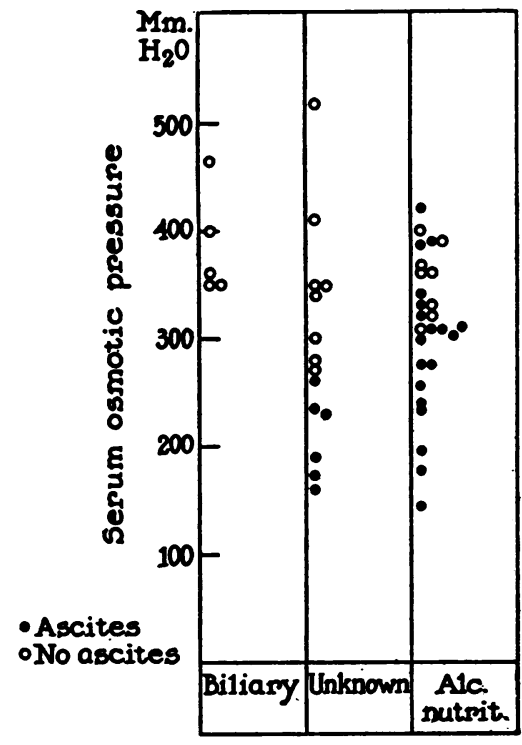

Fig. 2. Comparison of Serum Osmotic Pressure Measurements in Patients with Various Types of Cirrhosis

The wide spread of values associated with ascites in patients with alcoholic-nutritional type of cirrhosis is apparent.

of the cases represented cirrhosis following infectious hepatitis. There is a rather striking parallel between the serum osmotic pressure values of these patients with ascites and those described by Bjфrneboe, Brun, and Raaschou (12). In both groups, ascites was present when the serum osmotic pressure was below $260 \mathrm{~mm}$. of water, and absent if above this level. The patients with alcoholic cirrhosis, however, had ascites at levels of serum osmotic pressure up to $430 \mathrm{~mm}$. of water. The studies mentioned above $(12,13)$ were limited to cases of cirrhosis following hepatitis and did not include those related to alcoholism. From the present data, therefore, it would appear that ascites in patients with cirrhosis who have a high serum osmotic pressure is more frequently associated with the alcoholic nutritional type. The absence of a good correlation between serum osmotic pressure and ascites is further emphasized in patients with nephrosis or idiopathic hypoproteinemia. In two such patients, ascites developed at very low serum osmotic pressure levels and disappeared after diuresis despite little change in these low values. The findings agree with those of Muntwyler, Way, Binns, and Myers (10).

Since the difference between serum and ascitic fluid osmotic pressures is equal to the difference between the hydrostatic pressures of these fluids in accordance with Starling's hypothesis $(1,2$, 29), it seemed of interest to determine this osmotic difference in an attempt to evaluate the hydrostatic difference. The degree of elevation of this hydrostatic difference is related to the degree of elevation of the portal pressure because the portal bed represents the chief venous system in equilibrium with the ascitic fluid. The hydrostatic difference thus represents the "effective portal pressure" and not the total portal pressure. In order to obtain the total portal pressure the ascitic hydrostatic pressure would have to be determined and added to the "effective portal pressure." Difficulties in evaluating ascitic hydrostatic pressure as well as the realization that other venous channels in addition to the portal system might influence the equilibrium with ascitic fluid, made it preferable not to deal with the true portal pressure in this study. The term "effective portal pressure" is used in quotes because of the many known and unknown uncertainties involved in its indirect estimation from osmotic pressure differences.

Serial determinations of the osmotic pressure difference between serum and ascitic fluid demonstrated the constancy of this difference in individ-

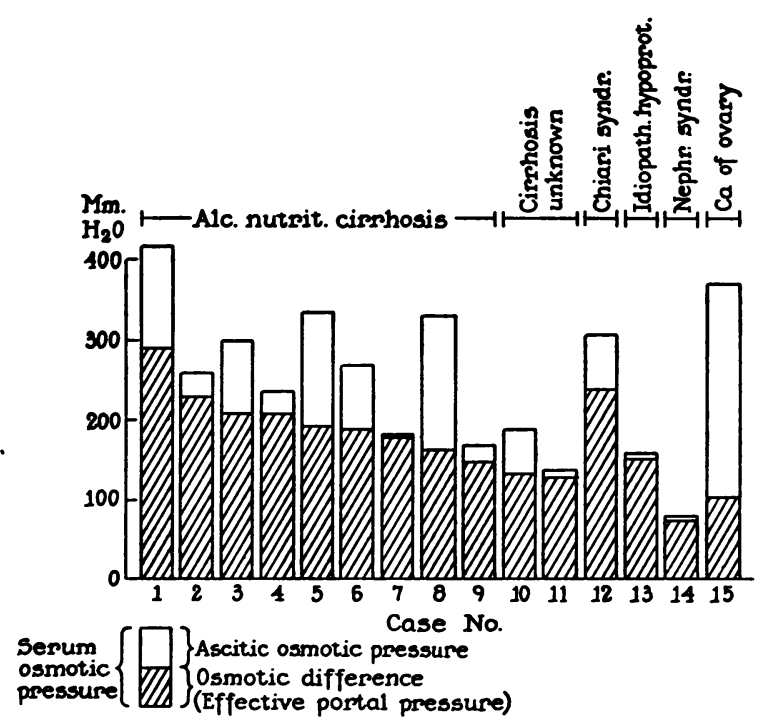

Fig. 3. Serum and Ascitic Fluid Osmotic Pressure Levels in Patients with Ascites Charted to Show the Serum-Ascitic Osmotic Pressure Difference INdicating "Effective Portal Pressure" in Certain Cases 
ual patients who showed little change in their general condition while being maintained in a steady state of protein equilibrium by the use of a controlled low sodium intake. In Figure 3, the serum and ascitic osmotic pressure values for 15 patients have been plotted. In 9 patients with alcoholic nutritional cirrhosis and in 1 patient with Chiari's syndrome, the osmotic difference (effective portal pressure) exceeded $150 \mathrm{~mm}$. of water. In 2 patients with cirrhosis of unknown etiology, it was approximately $135 \mathrm{~mm}$. of water. In Case 5, a porta-caval anastomosis was performed because of varices and refractory ascites. Postoperatively, the effective portal pressure fell only slightly, which correlated with other evidence of a poorly functioning shunt, namely, persistent ascites and a continued delayed portal circulation time of 31 seconds (30). The results in the patient with carcinoma of the ovary, similar to those obtained by others $(11,12)$ indicate a normal effective portal pressure.

An important limitation in the use of osmotic pressure measurements for the determination of "effective portal pressure" was found in patients where the serum osmotic pressure was close to or lower than the "effective portal pressure." This situation, assuming protein equilibrium, would bring about a maximum reduction of ascitic fluid osmotic pressure until at very low serum protein levels the ascitic fluid would no longer reflect the equilibrium conditions. In the present study it became apparent that in those cases where the

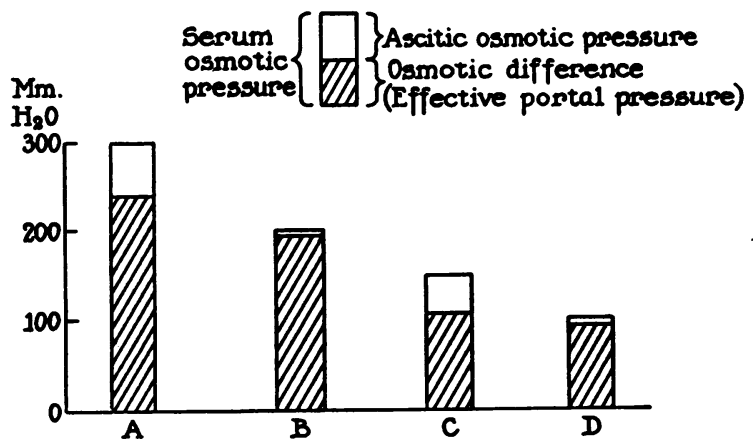

Fig. 4. Serum-Ascitic Fluid Osmotic Pressure Differences in Four Different Types of Cases of CirRHOSIS WITH Ascites

The "effective portal pressure" is not measurable in types $B$ and $D$ because the serum osmotic pressure is relatively too low to give a significant ascitic osmotic pressure. ascitic fluid osmotic pressure was less than $15 \mathrm{~mm}$. of water no true evaluation of the hydrostatic forces could be made. Figure 4 shows four types of cases that illustrate the various relationships encountered. In Case A, a high serum osmotic pressure and a sizeable ascitic osmotic pressure yields an elevated value for "effective portal pressure." In Case B, the ascitic osmotic pressure is too low to indicate the exact "effective portal pressure," although it is apparent that the value is high. Case C illustrates a low serum osmotic pressure with a sizable ascitic fluid osmotic pressure giving a relatively normal "effective portal pressure." In Case D, the ascitic fluid osmotic pressure is very low and in the presence of the low serum osmotic pressure little information regarding the height of the "effective portal pressure" can be obtained. Examples such as Cases B and D where the exact "effective portal pressure" cannot be determined are frequently encountered among patients with cirrhosis of the liver particularly those with unusually low serum osmotic pressure levels.

\section{DISCUSSION}

The possibility that the formation of ascites in patients with the alcoholic type of cirrhosis is related to the elevated "effective portal pressure" is suggested by the data obtained but remains unproven. Other possibilities acting more specifically in these patients than in others, such as adrenal effects causing increased sodium retention, posterior pituitary stimulation causing increased water retention, or special local abnormalities in lymphatic drainage, must be considered. The high "effective portal pressure" in cirrhosis found in this study and by Mankin and Lowell (2) is at variance with the concept that there is a generally applicable critical level of effective osmotic pressure below which ascites occurs (14).

It has been demonstrated by previous workers that changes in either serum or ascitic fluid protein are reflected by similar changes in the other fluid $(2,31,32)$ indicating a free exchange of protein across the peritoneal membrane. This is certainly important for calculation of the hydrostatic differences from the osmotic pressure difference between serum and ascitic fluid although much of the equilibrium is established by rapid interchange of water. The dynamic exchange of 
protein between ascitic fluid and serum was studied in this same group of patients by Eisenmenger and Slater (33) employing I ${ }^{131}$ tagged albumin and $\gamma$-globulin. A fall in specific activity for the serum and ascitic fluid on a single curve indicated the protein equilibrium.

The application of Starling's hypothesis to estimate total portal pressure was suggested first by Iversen (29), and has been discussed further by Mankin and Lowell (2). Since there are several unknown factors, however, this relationship cannot be used to quantitate the actual portal pressure. The most obvious unknown is the hydrostatic pressure of the ascitic fluid, which may vary depending on the amount of abdominal distention produced. Although certain standard and reproducible methods can be duplicated, the question must be raised whether any artificial measurement of ascitic hydrostatic pressure accurately describes the pressure exerted at the capillary membrane. Conflicting data have appeared in the literature in regard to the level of ascitic hydrostatic pressure $(2,3,29)$.

Since there are porta-systemic communications in the posterior peritoneum as well as systemic venous channels, the ascitic fluid is also partially in equilibrium with the systemic venous bed. The calculated "effective portal pressure" as obtained by osmotic pressure measurements would be lowered reflecting the extent of this communication, since the venous hydrostatic pressure is less by virtue of this connection with the systemic bed. Perhaps a value of the "effective portal pressure" particularly in relation to the total portal pressure measured directly at operation is that the latter is obtained in the large venous channels, whereas the "effective portal pressure" refers to the pressure in the capillary bed, where the level may be quite different (34). Certainly the term "effective portal pressure" as used in this study remains illdefined. The possibility that variations in the lymphatic system, which is known to transport most of the protein leaving the peritoneal cavity (35), may influence the osmotic pressure difference between serum and ascitic fluid must be considered. Direct measurement of portal pressure at laparotomy was carried out in five of the present group of patients. Although a general correlation with the serum-ascitic fluid osmotic pressure difference appeared to exist, the observations were too limited to draw any conclusions. One definite instance was encountered in a case of carcinoma of the ovary where the osmotic pressure difference appeared too great for a normal portal pressure. No explanation was apparent and indicates the probability of further unknown factors influencing this relationship.

Under equilibrium conditions the ascitic fluid osmotic pressure is primarily governed by the serum osmotic pressure and the hydrostatic forces of the abdominal venous system and ascitic fluid. It represents a very variable quantity that reflects the alterations in the other forces except where the osmotic pressure is less than $15 \mathrm{~mm}$. of water. A certain minimum protein concentration is still found in ascitic fluid even when the equilibrium forces are acting in a direction that would reduce the ascitic fluid osmotic pressure to a maximal extent. In patients with ascitic fluid associated with peritoneal carcinoma, the serum osmotic pressure is usually only slightly reduced and the effective portal pressure is close to normal. This would result in a high osmotic pressure in the ascitic fluid if equilibrium conditions prevail, and would explain the high protein content of such ascitic fluids without involving the concept of an exudate. Similarly in dogs with thoracic inferior vena cava constriction $(31,36)$ or constrictive pericarditis (37), the high ascitic protein concentration probably reflects this relationship between the serum osmotic pressure and the effective portal pressure. Thus, although Starling's hypothesis may not offer the main explanation for the formation of ascites, it nevertheless remains of great value in describing the equilibrium conditions and in accounting for the respective protein concentrations of serum and ascitic fluid.

\section{SUMMARY AND CONCLUSIONS}

1. Osmotic pressure measurements of the serum of patients with cirrhosis of the liver indicated that ascites was associated with levels ranging from the low value of $148 \mathrm{~mm} . \mathrm{H}_{2} \mathrm{O}$ to the high value of $418 \mathrm{~mm} . \mathrm{H}_{2} \mathrm{O}$. The higher levels of serum osmotic pressure were found primarily in patients with the alcoholic nutritional type of cirrhosis. In other types, the presence or absence of ascites appeared to be more directly related to a critical serum osmotic pressure level. 
2. An attempt at estimation of the "effective portal pressure" was made by determination of the difference between serum and ascitic fluid osmotic pressures in accordance with the Starling hypothesis, a steady state being maintained by means of a controlled low sodium diet.

3. The "effective portal pressure" could be estimated only if the serum osmotic pressure exceeded it by an amount sufficient to give a significant ascitic fluid osmotic pressure. This conditioning factor limited the application of these measurements. Other limitations are discussed.

4. High values for "effective portal pressure" were obtained in patients with cirrhosis forming ascites in the presence of high serum osmotic pressure levels.

\section{REFERENCES}

1. Starling, E. H., On the absorption of fluids from the connective tissue spaces. J. Physiol., 1896, 19, 312.

2. Mankin, H., and Lowell, A., Osmotic factors influencing the formation of ascites in patients with cirrhosis of the liver. J. Clin. Invest., 1948, 27, 145.

3. James, A. H., The mechanism of pleural and ascitic effusions, with a suggested method for the indirect estimation of portal venous pressure. Clin. Sc., 1949, 8, 292.

4. Govaerts, P., Influence de la teneur de sérum en albumines et en globulines sur la pression osmotique des protéines et sur la formation des cedèmes. Bull. Acad. roy. de méd. de Belgique, Ser. V, 1927, 7, 356.

5. Schade, H., and Claussen, F., Der onkotische Druck des Blutplasmas und die Entstehung der renal bedingten ödeme. Ztschr. f. Klin. Med., 1924, 100, 363.

6. Iversen, P., and Nakazawa, F., Uber die Biochemie des Filtrationsödems. Biochem. Ztschr., 1927, 191, 307.

7. Baráth, E., Klinische Beitrage zum Verhalten des onkotischen (Kolloidosmotischen) Druckes. I. Der onkotische Druck im serum des arteriellen und venösen Blutes bei kranken mit und ohne störungen im wasserhaushalt. Ztschr. f. Klin. Med., 1930, 114, 702.

8. Kerkhof, A. C., Plasma colloid osmotic pressure as a factor in edema formation and edema absorption. Ann. Int. Med., 1937, 11, 867.

9. Kylin, E., Studien über den kolloidosmotischen (onkotischen) Druck. XXVIII: Mitteilung: Tierexperimentelle Untersuchungen über die Bedeutung der Senkung des kolloidosmotischen Druckes für die Odempathogenese. Arch. f. exper. Path. u. Pharmakol., 1933, 170, 407.

10. Muntwyler, E., Way, C. T., Binns, D., and Myers, V. C., Plasma protein and plasma colloid osmotic pressure in pathological conditions with special ref- erence to the occurrence of edema. J. Clin. Invest., 1933, 12, 495.

11. Butt, H. R., Snell, A. M., and Keys, A., Plasma protein in hepatic disease: A study of the colloid osmotic pressure of blood serum and of ascitic fluid in various diseases of the liver. Arch. Int. Med., 1939, 63, 143.

12. Bjørneboe, M., Brun, C., and Raaschou, F., Colloid osmotic pressure in chronic hepatitis. Arch. Int. Med., 1949, 83, 539.

13. Higgins, G., Kelsall, A. R., O’Brien, J. R. P., Stewart, A. M., and Witts, L. J., Ascites in chronic disease of the liver. Quart. J. Med., 1947, 16, 263.

14. Armstrong, S. H., Jr., Mechanisms of action of serum albumin therapy in internal medicine. Am. J. Med., $1948,4,390$.

15. Balli, E. P., Robson, J. S., Clarke, D., and Hoagland, C. L., Factors influencing ascites in patients with cirrhosis of the liver. J. Clin. Invest., 1945, 24, 316.

16. Patek, A. J., Jr., Mankin, H., Colcher, H., Lowell, A., and Earle, D. P., Jr., The effects of intravenous injection of concentrated human serum albumin upon blood plasma, ascites and renal functions in three patients with cirrhosis of the liver. J. Clin. Invest., 1948, 27, 135.

17. Hepp, O., Ein neues Onkometer zur Bestimmung des kolloidosmotischen Drucks mit gesteigerter Messgenauigheit und vereinfachter Handhabung. Ztschr. f. d. ges. exper. Med., 1936, 99, 709.

18. Bigelow, S. L., and Gemberling, A., Collodion membranes. J. Am. Chem. Soc., 1907, 29, 1576.

19. Krogh, A., and Nakazawa, F., Beiträge zur Messung des Kolloid-osmotischen Druckes in biologischen Flüssigkeiten. Biochem. Ztschr., 1927, 188, 241.

20. Turner, A. H., The validity of determinations of the colloid osmotic pressure of serum. J. Biol. Chem., 1932, 96, 487.

21. Wies, C. H., and Peters, J. P., The osmotic pressure of proteins in whole serum. J. Clin. Invest., 1937, 16, 93.

22. Wells, H. S., A modified Krogh osmometer for the determination of the osmotic pressure of colloids in biological fluids (with directions for its use). J. Tenn. Acad. Sc., 1933, 8, 102.

23. Keys, A., The study of colloidal dimensions, thermodynamic activity, and the mean molecular weight of the mixed proteins in blood serum. J. Phys. Chem., 1938, 42, 11.

24. Peters, E., and Saslow, G., Performance of the Hepp micro-osmometer. J. Gen Physiol., 1939, 23, 177.

25. Keys, A., and Taylor, H., The determination of the colloidal osmotic pressure in blood serum and similar fluids. J. Biol. Chem., 1935, 109, 47.

26. Immergut, E., Personal communication.

27. Pierce, H. F., Nitrocellulose membranes of graded permeability. J. Biol. Chem., 1927, 75, 795.

28. Kunkel, H. G., Ahrens, E. H., Jr., Eisenmenger, W. J., Bongiovanni, A. M., and Slater, R. J., Extreme hypergammaglobulinemia in young women with 
liver disease of unknown etiology. J. Clin. Invest., 1951, 30, 654.

29. Iversen, P., Untersuchungen über die ascites-pathogenese. Klin. Wchnschr., 1928, 7, 2001.

30. Giges, B., and Teschan, P. E., The portal circulation time in cirrhosis of the liver following portacaval anastomosis. J. Lab. \& Clin. Med., 1952, 40, 537.

31. McKee, F. W., Schilling, J. A., Tishkoff, G. H., and Hyatt, R. E., Experimental ascites. Effects of sodium chloride and protein intake on protein metabolism of dogs with constricted inferior vena cava. Surg., Gynec., \& Obst., 1949, 89, 529.

32. Kunkel, H. G., Factors in the mechanism of ascites in Liver Disease, Ciba Foundation Symposium, Philadelphia, Blakiston, 1950, p. 130.

33. Eisenmenger, W. J., and Slater, R. J., Distribution and decay of $I^{181}$ tagged albumin and gamma glo- bulin in patients with cirrhosis. J. Clin. Invest., 1953, 32, 564.

34. Landis, E. M., The capillary blood pressure in mammalian mesentery as determined by the micro-injection method. Am. J. Physiol., 1930, 93, 353.

35. Courtice, F. C., and Steinbeck, A. W., The effects of lymphatic obstruction and of posture on the absorption of protein from the peritoneal cavity. Australian J. Exper. Biol. \& Med. Sc., 1951, 29, 451.

36. Volwiler, W., Grindlay, J. H., and Bollman, J. L., The relation of portal vein pressure to the formation of ascites-an experimental study. Gastroenterology, 1950, 14, 40.

37. Davis, J. O., Lindsay, A. E., and Southworth, J. L., Mechanisms of fluid and electrolyte retention in experimental preparations in dogs. I. Acute and chronic pericarditis. Bull. Johns Hopkins Hosp., $1952,90,64$. 